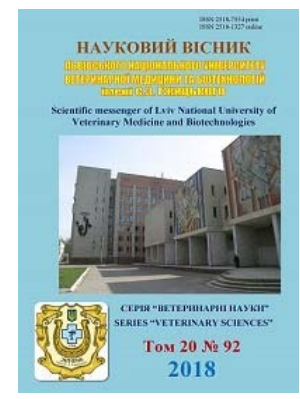

\author{
Науковий вісник Дьвівського національного університету \\ ветеринарної медицини та біотехнологій імені С.3. Гжицького
}

\author{
Scientific Messenger of Lviv National University \\ of Veterinary Medicine and Biotechnologies
}

ISSN 2518-7554 print

doi: $10.32718 /$ nvlvet9214

ISSN 2518-1327 online

http://nvlvet.com.ua

UDC 619: 619.591.1:636.084.52:636.4

\title{
Physiological state and productivity of young pigs for probiotic action
}

\author{
V.V. Voronyak, K.Y. Leskiv, V.O. Huberuk \\ Stepan Gzhytskyi National University of Veterinary Medicine and Biotechnologies Lviv, Ukraine
}

Article info

Received 18.10.2018

Received in revised form 16.11.2018

Accepted 19.11.2018

Stepan Gzhytskyi National University of Veterinary Medicine and Biotechnologies Lviv,

Pekarska Str., 50, Lviv,

79010, Ukraine.

Tel.: +38-067-179-69-86

E-mail:v.voronyak7@gmail.com
Voronyak, V.V., Leskiv, K.Y., \& Huberuk, V.O. (2018). Physiological state and productivity of young pigs for probiotic action. Scientific Messenger of Lviv National University of Veterinary Medicine and Biotechnologies, 20(92), 68-72. doi: 10.32718/nvlvet9214

Due to the impact of adverse environmental factors, unsatisfactory conditions of pig population, deterioration of food supply, abuse of antibiotics, lack of preventive measures, leads to the development of diseases among pigs, especially young, which leads to a decrease in resistance, body performance, reproduction and reduction of livestock, as well as large economic losses. The use of bacterial preparations from living microorganisms can significantly reduce or even eliminate the use of antibiotics and hormones in the cultivation of healthy animals, to obtain high-quality and safe high-grade products. The aim of the work is to study the effect of probiotic EM-1 on the physiological state and productivity of young pigs of large white breed. The experiment was conducted on two groups ( 6 heads each) of animals-analogues, starting from 60 days of age, for 2 months. Animals of the control group received feed produced in the farm. Piglets of the experimental group in addition to the main diet received $5 \%$ of feed fermented with em-1. Evaluation of the physiological state and productivity of young pigs was carried out on 60, 90 and 120 days of experience according to the methods adopted in clinical practice. Hygienic, hematological, biochemical, zootechnical and statistical methods of research were used in the performance of the work. The use of probiotic EM-1 in animals of the experimental group led to an increase in hemoglobine concentration by $7.7 \%$, an increase in the number of red blood cells by $13.7 \%$, the total number of leukocytes by $9.52 \%$, and glucose concentration by $11.4 \%$. The advantage of the viability of these pigs for the content of total protein $(P<0.05), \gamma-$ globulins by $18.6 \%$, the activity of aminotransferases (AlAT, AsAT; $P<0.05$ ), the average daily gain increased by $12.3 \%$ at the end of the experiment. For feeding piglets feed with probiotic EM-1 increased metabolic processes, resistance and productivity of the body, which indicates a higher level of redox reactions in their body.

Key words: young pigs, probiotic EM-1, physiological state, productivity.

\section{Фізіологічний стан і продуктивність молодняку свиней за дії пробіотику}

\author{
В.В. Вороняк, Х.Я. Леськів, В.О. Губерук
}

Львівський національний університет ветеринарної медицини та біотехнологій імені С.3. Гюицького, м. Львів, Україна

Вплив несприятливих чинників довкілля, незадовільних умов утримання поголів 'я свиней, погіршення кормової бази, зловживання антибіотиками, недостатність профілактичних заходів тощо, призводить до розвитку захворювань серед свиней, особливо молодняку, що спричиняє зниження стійкості, продуктивності організму, порушення відтворення $i$ скорочення поголів'я, $i$, як наслідок великих економічних збитків. Застосування бактеріальних препаратів із живих мікроорганізмів дає змогу значно скоротити або взагалі виключити використання антибіотиків і гормональних препаратів при вирочуванні здорових тварин, одержувати якісну та безпечну повноцінну продукиію. Мета роботи - вивчити вплив пробіотику ЕМ-1 на фізіологічний стан та продуктивність молодняку свиней великої білої породи. Протягом 2-ох місяиів проведено дослід на двох групах (по 6 голів у кожній) тварин-аналогів, починаючи з 60-денного віку. Тварини контрольної групи отримували комбікорм, щсо виробляється в умовах ферми. Поросята дослідної групи у додаток до основного раціону одержували 5\% комбікорму, ферментованого препаратом ЕМ-1. Оцінку фізіологічного стану та продуктивності молодняку свиней проводили на 60, 90 і 120 дні досліду за методиками, прийнятими у клінічній практиці. При виконанні роботи використовували гігієнічні, гематологічні, біохімічні, зоотехнічні та статистичні методи дослідженнь. Використання пробіотику ЕМ-1 тваринам дослідної групи призвело до підвищення концентрації гемоглобіну на 7,7\%, збільшення кількості еритроцитів на 13,7\%, загальної кількості лейкоцитів на 9,5\%, концентрації глюкози на 11,44\%. Виявлено перевагу життестійкості ичих поросят за вмістом загального білка $(P<0,05)$, $\gamma$-глобулінів на 18,6\%, активністю амінотра- 
нсфераз (АлАТ, АсАТ; Р < 0,05); середньодобові прирости збільшувались на 12,3\% наприкінці експерименту. За згодовування поросятам комбікорму з пробіотиком ЕМ-1 зростали метаболічні процеси, резистентність та продуктивність організму, ичо вказує про вищий рівень окислювально-відновлювальних реакцій в їхньому організмі.

Ключові слова: молодняк свиней, пробіотик ЕM-1, фізіологічний стан, продуктивність.

Вступ

У світі намітилась чітка тенденція до виробництва якісних та безпечних продуктів тваринництва. Але, зростаюче забруднення довкілля, погіршення кормової бази, скорочення витрат на профілактичні заходи щодо попередження хвороб тварин, порушення технології утримання поголів'я, зловживання антибіотиками тощо призводить до масового розповсюдження захворювань серед тварин, особливо молодняку, що веде до зниження продуктивності, порушення відтворення і скорочення поголів'я (Demchuk et al., 2006; Zelenuha and Grechuhin, 2011; Medvediev et al., 2015).

За незадовільних умов утримання поголів'я молодняку свиней рівень його стійкості та продуктивності істотно знижується. На це впливають несприятливі чинники довкілля, причому свині з вищою продуктивністю різкіше реагують на погіршення умов годівлі, догляду та утримання (Demchuk et al., 2006; Chorniy et al., 2017; Zhukova et al., 2017; Khimich et al., 2017). Щорічно у господарствах України хворіють 60-80\% новонароджених, а загибель поросят за захворювань травного тракту, за даними ряду авторів (Cherniy et al., 2018), сягає від 41,3 до 81,9\%.

У цьому зв'язку особливо актуальними є дослідження, які спрямовані на вишукування прийомів, 3 метою забезпечення високої життєстійкості, збереженості та продуктивності молодняку (Kosenko et al., 2007; Voroniak, 2009; Balym et al., 2012; Hunchak and Sedilo, 2017; Todoriuk et al., 2018).

Пріоритетними є дослідження з інтенсифікації вирощування та відгодівлі свиней, розробки системи годівлі, що забезпечує підвищення темпів зростання та економніше використання коштовних кормових засобів (Zhil'cov, 2000; Medvediev et al., 2015). Одним із методів вирішення цього завдання $є$ додавання до кормів ферментів, пробіотиків, мінеральних речовин та вітамінів, особливо за сучасних умов виробництва, що зв'язано з підвищеною концентрацією поголів'я, зниженням їх рухливості, браком інсоляції, недотриманням мікрокліматичних умов та ветеринарносанітарних вимог (Gajnullina, 2004; Holovko and Khomutovska, 2011; Sidashova et al., 2014).

Сучасний виклик галузі полягає в тому, як втримати продуктивність і ефективність вирощування свиней, до того ж подолавши тиск щодо зниження залежності від антибіотиків (Demchuk et al., 2006; Holovko and Khomutovska, 2011).

Найбільш виправданим, 3 екологічних позицій, методом санації бактеріоносіїв та збудників кишкової інфекції $є$ застосування бактеріальних препаратів 3 живих мікроорганізмів, здатних проявляти антагоністичну i конкурентну дію стосовно до патогенних мікробів (Kosenko et al., 2007; Voroniak, 2009; Sidashova et al., 2014).
До них відносять, в основному пробіотики, які сприяють відновленню нормоценозу травного тракту, нормалізують обмін білків, жирів, вуглеводів, мінеральних речовин за рахунок активнішого утворення та використання біологічно активних речовин, ферментів, поліпшують гематологічні та біохімічні показники крові. Препарати на основі молочнокислих бактерій, крім імуномоделювальних, проявляють також антиоксидантні властивості завдяки продукуванню таких метаболітів як вітаміни групи В, молочна кислота і лізоцим. У результаті цього зменшується захворюваність, підвищується резистентність і продуктивність тварин (Kovalenko and Zinov'ev, 2004; Stehnii and Huzhvynska, 2005; Voroniak, 2009; Pryskoka et al., 2010).

Патологічні мікроорганізми, розмножуючись у кишечнику, споживають вітаміни і амінокислоти, утруднюють всмоктування жиророзчинних вітамінів, володіють здатністю безпосередньо руйнувати травні ферменти господаря. Внаслідок цього виникають такі проблеми як недостатнє засвоєння корму, неінфекційний гепатит, панкреатит, аліментарний алергічний дерматит i iнші захворювання людей i тварин (Gajnullina, 2004; Kosenko et al., 2007).

У результаті введення в раціон тварин препаратів ефективних мікроорганізмів відбувається нормалізація кишкової мікрофлори, посилюється імунітет, підвищується продуктивність внаслідок поліпшення засвоєння кормів. Літературні дані вказують на позитивний вплив ЕМ-препаратів на ріст і розвиток молодняку тварин. Так, прирости у телят збільшуються в середньому на 23-33, а поросят - 17-25\% (Kovalenko and Zinov'ev, 2004; Voroniak, 2009).

Застосування ЕМ дозволяє значно скоротити або взагалі виключити використання антибіотиків і гормональних препаратів за вирощування здорових тварин, одержувати якісну та безпечну повноцінну продукцію. Колонізація свинарників корисними мікроорганізмами призводить до зниження вмісту аміаку, сірководню, а також знижує ризик інфекції та хвороб (Voroniak, 2009).

Мета роботи - вивчити вплив пробіотику ЕМ-1 на деякі гематологічні, біохімічні показники крові та продуктивність молодняку свиней.

\section{Матеріал і методи досліджень}

Упродовж 2-ох місяців проведено дослід на двох групах (по 6 тварин у кожній) тварин-аналогів, починаючи 3 60-денного віку. Поросята утримувались у групових станках типового свинарника ФГ "Крись" Самбірського району Львівської області. Поросята контрольної групи отримували основний раціон, до складу якого входила дерть зерносуміші (пшениці та ячменю в співвідношенні 50:50) 3 додаванням преміксу (виробник ТзОВ “Провімі”). До основного раціону 
тваринам дослідної групи додавали 5\% комбікорму, ферментованого препаратом ЕМ-1.

Матеріалом для дослідження служила кров обох груп поросят у 60- і 120-денному віці, у якій визначали кількість еритроцитів і лейкоцитів, рівень гемоглобіну, вміст загального білка та його фракцій, глюкози, активність амінотрансфераз за загальновизнаними методами досліджень.

Здійснювався щоквартальний хімікотоксикологічний аналіз якості кормів. Тварин зважували у віці 60, 90 і 120 днів. Цифровий матеріал обробляли методом варіаційної статистики на персональному комп’ютері за програмою “Статистика”.

\section{Результати та їх обговорення}

Створення мікроклімату в приміщеннях відповідно до віку, виду та продуктивності поголів'я є головною умовою для його доброго самопочуття (Demchuk et al., 2006). За період дослідження показники мікроклімату в приміщенні коливались залежно від часу доби та періоду досліджень: так середньомісячна температура повітря у березні становила 13,15- $16,28^{\circ} \mathrm{C}$, у квітні $-15,12-16,85^{\circ} \mathrm{C}$, у травні - 16,30 $18,5{ }^{\circ} \mathrm{C}$. Відносна вологість (75-85\%) та швидкість руху повітря $(0,15-0,62 \mathrm{M} / \mathrm{c})$ незначно перевищували

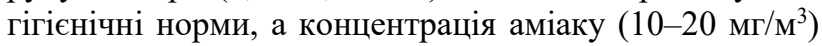
та вуглекислоти $(0,12-0,25 \%)$ була в межах гранично допустимих концентрацій.

У результаті спостережень за поросятами встановлено, що тварини дослідної групи були активнішими, мали гладку блискучу шерсть і рожевий колір шкіри.

Отримані при дослідженні результати, наведені в таблиці 1, вказують про позитивний вплив ферментованого корму на організм, який додавали до основного раціону дослідній групі тварин. Так, після закінчення експерименту кількість еритроцитів у крові тварин дослідної групи була більшою ніж в контрольних в 120 -добовому віці на $13,7 \%$ ( $<<0,05)$, а рівень гемоглобіну в ці ж періоди виявився вищим на 7,7\% відповідно. Отже, цей факт підтверджує наші припущення про підсилення процесів біосинтезу в організмі дослідних свиней, оскільки в них покращувалася оксигенація тканин, що забезпечувало вищий рівень енергетичного обміну.

\section{Таблиця 1}

Динаміка гематологічних та біохімічних показників крові поросят після згодовування ферментованого корму, $\mathrm{M} \pm \mathrm{m}, \mathrm{n}=6$

\begin{tabular}{|c|c|c|c|}
\hline \multirow{2}{*}{ Показники } & \multirow{2}{*}{ Група } & \multicolumn{2}{|c|}{ Вік тварин, доба } \\
\hline & & 60 & 120 \\
\hline \multirow{2}{*}{ Гемоглобін, г/л } & Контрольна & $103 \pm 2,1$ & $105 \pm 1,94$ \\
\hline & Дослідна & $104 \pm 1,87$ & $113 \pm 2,54$ \\
\hline \multirow{2}{*}{ Еритроцити, т/л } & Контрольна & $6,29 \pm 0,12$ & $6,43 \pm 0,16$ \\
\hline & Дослідна & $6,38 \pm 0,12$ & $7,33 \pm 0,16^{*}$ \\
\hline \multirow{2}{*}{ Лейкоцити, г/л } & Контрольна & $9,33 \pm 0,33$ & $10,30 \pm 0,53$ \\
\hline & Дослідна & $9,28 \pm 0,22$ & $11,29 \pm 0,58^{*}$ \\
\hline \multirow{2}{*}{ Загальний білок, г/л } & Контрольна & $69,82 \pm 2,61$ & $72,9 \pm 2,35$ \\
\hline & Дослідна & $70,24 \pm 1,75$ & $81,8 \pm 2,25^{*}$ \\
\hline \multirow{2}{*}{ АлАТ, мккат/л } & Контрольна & $0,44 \pm 0,025$ & $0,48 \pm 0,024$ \\
\hline & Дослідна & $0,45 \pm 0,027$ & $0,60 \pm 0,030^{*}$ \\
\hline \multirow{2}{*}{ AcАТ, мккат/л } & Контрольна & $0,49 \pm 0,026$ & $0,61 \pm 0,023$ \\
\hline & Дослідна & $0,50 \pm 0,025$ & $0,77 \pm 0,026^{*}$ \\
\hline
\end{tabular}

Примітка: ${ }^{*}-\mathrm{P}<0,05$ порівняно з показниками контрольної групи тварин

У поросят дослідної групи в кінетиці показників лейкограми відбулось підвищення (на 9,52\%) загальної кількості лейкоцитів за рахунок збільшення вмісту лімфоцитів і моноцитів, що можна розглядати як показник поліпшення природної резистентності організму. У контрольній групі тварин кількість лейкоцитів зростала за рахунок паличко- і сегментноядерних нейтрофілів.

Аналіз стану вуглеводного обміну свідчить про те, що концентрація глюкози в крові молодняку свиней протягом періоду застосування пробіотика, зростала та у 120-добовому віці перевищувала аналогічні показники поросят контрольної групи на 11,44\%. Це вказує про значно високу потребу їх тканин в глюкозі як джерелі енергії, що необхідна для забезпечення метаболічних процесів в організмі зростаючих тварин під дією препарату ЕМ-1.

Одним 3 важливих показників метаболізму у тварин є кількість білків крові та їх якісна характеристи- ка. Згодовування тваринам ферментованого корму стимулювало функціональний стан їхньої печінки, який проявився в посиленні синтезу сироваточного альбуміну і підвищенні його рівня в сироватці крові у 120-денних поросят. Рівень загального білка сироватки крові піддослідних тварин також збільшилась (Р < 0,05) порівняно 3 контрольною групою. Результати досліджень показали підвищення кількості $\gamma$ глобулінів на 18,6\%, що вказує про поліпшення резистентності організму.

У підтримці нормального рівня загального білка в організмі беруть участь амінотрансферази (АсАТ i АлАТ), які за посилення синтезу білка запускають процеси переамінування. При визначенні активності амінотрансфераз (АлАТ, АсАТ) встановлено, що ї активність зростає (Р < 0,05 ) у тварин дослідної групи. Існує твердження про те, що активність аланінамінотрансферази чутлива до якості білка. Можливо, більш низька активність цього ферменту в контроль- 
ній групі поросят вказує про дефіцит деяких амінокислот у згодовуваних кормах, що проявляється подібно до дефіциту білка, затримуючи ріст тварин. Використання мікробіологічного препарату ЕМ-1 для ферментації кормів сприяє збагаченню їх вільними амінокислотами, в тому числі незамінимими. Виявляється також тенденція до зростання активності аспартатамінотрансферази у тварин контрольної групи, але цей показник залишається в межах величин фізіологічної норми. Про вищий рівень окиснювальновідновлювальних реакцій в організмі поросят за згодовування пробіотиків (підвищення морфологічних, біохімічних та імунологічних показників) свідчать експерименти ряду авторів (Cherniy et al., 2018).
Переконливо доведено позитивний вплив ЕMферментованого корму на організм поросят $€$ зміна живої маси протягом досліду (табл. 2). Так, маса однієї тварини за першого зважування у всіх групах в середньому становила 15,19 $\pm 0,68$ кг. У віці 90 діб середньодобовий приріст молодняку свиней дослідної групи перевищував результат контрольної групи на $3,6 \%$. За період експерименту найвищі показники середньодобових приростів відзначали у тварин 120денного віку дослідної групи, що призвело до збільшення $(\mathrm{P}<0,05)$ їхньої живої маси. На сприяння енергії росту, збереженості молодняку свиней за використання пробіотиків вказують інші дослідження (Sidashova et al., 2014; Cherniy et al., 2018).

Таблиця 2

Динаміка змін живої маси та середньодобового приросту поросят після згодовування ЕМ-ферментованого корму

\begin{tabular}{cccc}
\hline Вік тварин & Група & Жива маса,кг & Середньодобовий приріст, г \\
\hline \multirow{2}{*}{60 діб } & Контрольна & $15,15 \pm 0,68$ & - \\
& Дослідна & $15,23 \pm 0,66$ & $456 \pm 13,3$ \\
\multirow{2}{*}{90 діб } & Контрольна & $28,9 \pm 0,81$ & $513 \pm 15,6$ \\
\multirow{2}{*}{120 діб } & Дослідна & $29,5 \pm 0,82$ & $495 \pm 14,6$ \\
& Контрольна & $43,7 \pm 1,14$ & $556 \pm 16,1^{*}$ \\
\hline
\end{tabular}

Примітка: ${ }^{*}-\mathrm{P}<0,05$ порівняно з показниками контрольної групи тварин

\section{Висновки}

1. За впливу пробіотика ЕМ-1 зростають метаболічні процеси у тканинах поросят, що позначається на підвищенні в крові кількості еритроцитів, лейкоцитів, загального білка, а також зростанні активності амінотрансфераз.

2. Використання препарату ефективних мікроорганізмів під час вирощування поросят дозволяє поліпшити в їхньому організмі обмін вуглеводів, підвищити масу тіла та зберегти поголів'я тварин за рахунок підсилення імунітету.

Перспективи подальших досліджень. Вивчення морфологічного складу свинини та ії фізико-хімічних показників після згодовування препарату EM-1 у забитих тварин.

\section{References}

Balym, Yu.P., \& Lemishko, O.Ia., \& Donskykh O.D. (2012). Vplyv probiotyku "Biosvit" na fiziolohichni ta produktyvni pokaznyky. Naukovyi visnyk LNUVMBT imeni S.Z. Gzhytskoho, 14, 2(52), 3-7. http://nbuv.gov.ua/UJRN/nvlnu $2012 \quad 14 \quad 2 \% 282 \% 29$ 3 (in Ukrainian).

Cherniy, N.V., Matsenko, E.V., Shchepetilnikov, Yu.A., Maslak, Yu.V., Machula, O.S., Furda, I.V., Voronyak, V.V., \& Gutyj, B.V. (2018). Influence of the supplement "Press-Acid" on proteinmineral metabolism and resistance of piglets. Scientific Messenger of Lviv National University of Veterinary Medicine and Biotechnologies, 20(83), 320-324. doi: $10.15421 /$ nvlvet 8364 .

Chorniy, N.V., Machula, O.S., Voronyak, V.V., Lyasota, V.P., \& Reshetnichenko, O.P. (2017). Productivity and resistance of pigs under the action of immunostimulants. Scientific Messenger LNUVMB, 19(79), 83-86. doi: 10.15421/nvlvet7917.

Demchuk, M.V., Reshetnyk, A.O., Banas, T.V., \& Bohachyk, O.H. (2006). Porivnialna dobrobutna otsinka suchasnykh intensyvnykh tekhnolohii vyrobnytstva svynyny. Nauk.visnyk LNAVM im. S.Z. Gzhytskoho, 8, 2(29), 48-55 (in Ukrainian).

Gajnullina, M. (2004). Dobavki deshevle, a pribyli vysokie. Zhivotnovodstvo Rossii, 4, 16-17 (in Russian).

Holovko, V.O., \& Khomutovska, S.O. (2011). Suchasnyi pohliad na pidvyshchennia rezystentnosti ta profilaktyky khvorob $\mathrm{v}$ riznykh sanitarnohihiienichnykh umovakh. Problemy zooinzhenerii ta veterynarnoi medytsyny: Zb. nauk. pr. KhDZVA, 23(2), 559-562 (in Ukrainian).

Hunchak, R.V., \& Sedilo, H.M. (2017). Iodine deficiency in pigs and the solutions to the problem. Scientific Messenger LNUVMBT named after S.Z. Gzhytskyj, 19(74), 208-214. doi: 10.15421/nvlvet7445.

Khimich, M.S., Gorobei, A.M., Kozulin, F.V., \& Zhekov, V.V. (2017). Monitoring of safety and quality products slaughter of pigs obtained in Odessa region. Scientific Messenger LNUVMBT named after S.Z. Gzhytskyj, 19(77), 148-152. doi: 10.15421/nvlvet7732.

Kosenko, M., Muzyka, V., Kosenko, Yu., \& Stetsko, T. (2007). Ratsionalne vykorystannia antymikrobnykh preparativ yak faktor strymuvannia rozvytku antybiotykorezystentnosti. Veterynarna medytsyna Ukrainy, 8, 40-41 (in Ukrainian).

Kovalenko, V.F., \& Zinov'ev, S.G. (2004). Biohimija i morfologija krovi porosjat pri kormlenii $\mathrm{s}$ dobavleniem prepa-rata "Bajkal JeM-U". Nadezhda planety, 7, 3-6 (in Russian). 
Medvediev, V.O., Tsereniuk, O.M., Stryzhak, T.A., Khvatova, M.A., \& Liashenko, N.V. (2015). Obgruntuvannia udoskonalennia norm hodivli svynei riznoho napriamu produktyvnosti. Naukovyi visnyk NUBiP, 205, 162-172 (in Ukrainian).

Pryskoka, V.A., Sobko, Yu.A., \& Panchenko, O.O. (2010). Mikroorhanizmy: zmina spivvidnoshen mizh populiatsiiamy ta nadlyshkovyi rist yak peredumova vynyknennia zakhvoriuvan. Veterynarna medytsyna, 9, 30-33 (in Ukrainian).

Sidashova, S.O., Avdosieva, I.K., \& Hryhorasheva, I.M. (2014). Metodychnyi pidkhid do otsinky efektyvnosti vykorystannia probiotychnykh preparativ u svynarstvi. Nauk.-tekhn. biuleten IB i DNDKI vetpreparativ ta kormovykh dobavok, 15(4), 158-167. http://nbuv.gov.ua/UJRN/Ntbibt_2014_15_4_33 (in Ukrainian).

Stehnii, B.T., \& Huzhvynska, S.O. (2005). Probiotyky v tvarynnytstvi. Visnyk ahrarnoi nauky, 2, 26-29 (in Ukrainian).
Todoriuk, V.B., Hunchak, V.M., Gutyj, B.V., Gufriy, D.F., Hariv, I.I., Khomyk, R.I., \& Vasiv, R.O. (2018). Preclinical research of the experimental preparation "Ferosel T". Ukrainian Journal of Veterinary and Agricultural Sciences, 1(1), 3-9. doi: 10.32718/ujvas1-1.01.

Voroniak, V.V. (2009). Zastosuvannia efektyvnykh mikroorhanizmiv u silskomu hospodarstvi ta okhoroni dovkillia. Lviv: LNUVM ta BT imeni S.Z. Gzhytskoho (in Ukrainian).

Zelenuha, E.A., \& Grechuhin, A.N. (2011). Meroprijatija pri respiratornyh boleznjah svinej $\mathrm{v}$ promyshlennyh kompleksah. Suchasna veterinarna medicina, 3, 28-31 (in Russian).

Zhil'cov, N.V. (2000). Pravil'noe ispol'zovanie korma osnova vygodnogo proizvodstva svininy. Svinovodstvo, 1, 11-13 (in Russian).

Zhukova, I.O., Molchanov, A.A., \& Antipin, S.L. (2017). Increase in resistance of pigs to oxidative stress by means of plant origin. Scientific Messenger LNUVMBT named after S.Z. Gzhytskyj, 19(74), 3337. doi: 10.15421/nvlvet7408. 